\title{
An Integrated Approach to Analyzing (Adaptive) Comanagement Using the "Politicized" IAD Framework
}

\author{
Luke Whaley $^{1}$ and Edward K. Weatherhead ${ }^{1}$
}

\begin{abstract}
Scholars of comanagement are faced with a difficult methodological challenge. As comanagement has evolved and diversified it has increasingly merged with the field of adaptive management and related concepts that derive from resilience thinking and complex adaptive systems theory. In addition to earlier considerations of power sharing, institution building, and trust, the adaptive turn in comanagement has brought attention to the process of social learning and a focus on concepts such as scale, self-organization, and system trajectory. At the same time, a number of scholars are calling for a more integrated approach to studying (adaptive) comanagement that is able to situate these normative concepts within a critical understanding of how context and power fundamentally influences the behavior of a system. We propose that the "politicized" version of the Institutional Analysis and Development (IAD) Framework, originally developed by Elinor Ostrom and her colleagues, is well suited to addressing this challenge. The framework provides breadth, clarity, and structure by drawing the analyst's attention to the range of variables and questions to be considered when attempting a study of comanagement, the various components of the situation, and the ways in which they interact, and the criteria the analyst may wish to adopt in evaluating the outcomes of the process. Alongside its ability to address contextual factors and power dynamics, the socioeconomic and institutional dimension of the politicized IAD Framework means that it can be used to conduct analyses that result in sound policy recommendations.
\end{abstract}

Key Words: comanagement; adaptive comanagement; IAD Framework; politicized IAD Framework; methodology; institutions; power; discourse; resilience

\section{INTRODUCTION}

Many of the world's habitats and ecosystems are failing because of human activity and many more are under threat and face an uncertain future; yet at the same time a growing global population and changing lifestyle preferences are only set to exacerbate these issues in the coming years (UNEP 2012). A tremendous amount of work has concerned itself with potential solutions to the difficult problems associated with ecosystem loss and natural resource management, attracting the attention of scholars working within and across different disciplines. Among academics and practitioners there is a growing appreciation of the shortfalls associated with a one-size-fits-all approach to environmental governance (Meinzen-Dick 2007, Ostrom 2007) and an awareness that centralized and bureaucratic attempts to manage the environment tend to be exclusionary, reactive, insensitive to changing circumstances, and prone to result in pathological outcomes (Holling and Meffet 1996, Glasbergen 1998, Pahl-Wostl 2007, Pahl-Wostl et al. 2007). In the place of top-down governance a suite of institutional arrangements have emerged as viable alternatives in particular circumstances, ranging from markets in natural resources to community-based systems of management (de Loë et al. 2009). One approach that links centralized and decentralized forms of governance across scales of organization and is gaining increasing attention as a means of addressing these challenges is comanagement.

Comanagement has its roots in the work of commons scholars (Kearney 1984, McCay and Acheson 1987, Pinkerton 1989a), although in the last decade it has increasingly merged with the field of adaptive management and related concepts found in resilience thinking and complex adaptive systems theory (Holling 1978, Lee 1993, Levin 1999, Folke 2006). This merger has tended to combine the linkages typical of comanagement with the learning dimension associated with adaptive management, resulting in what has been termed "adaptive comanagement"
(Olsson et al. 2004a, Armitage et al. 2007, 2009). The crossdisciplinary nature of (adaptive) comanagement demands a wide methodological breadth that is able to encompass concepts and approaches deriving from both the natural and the social sciences. Thus a challenge for comanagement scholars relates to the need to develop a common framework that is capable of addressing the many dimensions of comanagement across differing physical and social settings, and to ground the normative concepts associated with the subject in a critical awareness of how context fundamentally influences process and outcomes.

We discuss how a version of the Institutional Analysis and Development (IAD) Framework, originally developed by Ostrom and her colleagues (Kiser and Ostrom 1982, Ostrom 1990, 2005, 2010) but that has been adapted by Clement (2010) to explicitly consider important contextual variables, can be used to analyze comanagement. To do this we briefly review comanagement and the developments it has undergone since its establishment as a concept in the 1980s, as well as the methodological challenges associated with the study of the subject. We provide an overview of the "politicized" IAD Framework as proposed by Clement, before discussing how this framework is well suited to analyses of comanagement. We conclude with a synopsis of the main points of the discussion.

\section{THE DEVELOPMENT OF COMANAGEMENT THEORY}

Emerging as a branch of commons theory, comanagement has come to be seen by some as a fourth ideal form of property-rights regime alongside the government, market, and community (Imperial and Yandle 2005). At the same time, "co-management is not envisioned as a replacement for central government, nor is it incompatible with existing market-based systems; it is a supplement to these decision-making processes" (Plummer and Fitzgibbon 2004:63). Despite its common point of origin in the academic literature, the concept of comanagement has since been 
influenced by a diverse group of scholars, managers, and commentators, resulting in variegated explanations of the term as one moves from place to place, resource to resource, or between different junctures in time. Nonetheless, rather than contradicting themselves, these conceptions of comanagement instead serve to highlight the multifaceted nature of the subject, as well as the conceptual developments that have occurred as new insights have emerged, different analytical approaches have been adopted, and previously separate fields of enquiry have come together.

One way of interpreting these various conceptions of comanagement has been provided by Berkes (2009), who charts the development of the term from its initial focus on structural dimensions through to an appreciation of complexity and the need to give precedence to function and process. From this perspective, early attempts at analyzing comanagement tended to focus on formal power-sharing arrangements between a community of resource users and a central government (Berkes et al. 1991), the development of adequate levels of trust between participants (Pinkerton 1989b, Daniels and Walker 1996, Ostrom 1999a, Leach and Pelkey 2001), and institution building both at the local level and between levels of organization (Jentoft 1989, Pomeroy and Berkes 1997). Increasingly, however, consideration was given to the temporal dimension of comanagement and "how different management tasks are organized and distributed, concentrating on the function, rather than the structure, of the system" (Carlsson and Berkes 2005:73).

This change in focus has turned attention toward the mechanisms through which the process of comanagement proceeds. Here scholars have found fertile ground in merging the narratives of comanagement and adaptive management, where the former's attention to system linkages complements the latter's concern with problem solving and learning-by-doing. The merger of these two fields, each with their own distinct disciplinary histories, has resulted in what has come to be called adaptive comanagement (Olsson et al. 2004a, Armitage et al. 2007, 2009). This development has propelled comanagement into the realm of complex adaptive systems theory and resilience thinking, in which concepts such as scale, self-organization, and emergence have established themselves in the discourse (Levin 1999, Olsson et al. 2004b, Folke 2006). It has also placed a strong focus on the concept of social learning as a means by which the multiple perspectives represented in a system of comanagement are to jointly learn about and adapt to change and uncertainty (Armitage et al. 2008).

The adaptive turn has also brought attention to earlier depictions that portrayed comanagement as a binary relationship between a homogenous community of resource users and a monolithic government. It is recognized that neither the government, nor a community of resource users are simple entities acting in unison but instead can themselves be thought of as complex systems comprising networks of individuals and groups. In an attempt to elucidate this perspective, Carlsson and Berkes (2005) have put forward the idea of "comanagement as governance," whereby the system of management can be described in terms of the networks and institutions that emerge as a result of the process of collaboration. This version of comanagement "encompasses the idea that in many real-life cases, we can expect to find rich webs of relations and agreements linking different parts of the public sector to a similarly heterogeneous set of private actors, all within the same area or within the same resource system" (Carlsson and Berkes 2005:69).

\section{METHODOLOGICAL CONSIDERATIONS}

The above short synopsis shows how comanagement can be thought of in terms of power sharing, trust building, institution building, process, problem solving, social learning, and as governance (Berkes 2007, 2009, Plummer and Armitage 2007a). All aspects of comanagement are valid and convey important messages. Furthermore, for analytical purposes it is helpful to distinguish between the various ways in which comanagement can be understood, but in reality the boundaries of these categories are permeable, allowing each to flow into the other. However, the "many faces" of comanagement (Berkes 2007) provides a methodological challenge to those attempting to study it. The cross-disciplinary nature of the subject permits scope for investigating comanagement according to the tenets of a range of distinct and sometimes seemingly incompatible scholarly lineages. The adaptive turn in comanagement has brought in concepts and perspectives that stem from the natural sciences, whereas the large social and institutional component of the subject, in which issues of power, collaboration, and conflict abound, plants comanagement firmly in the social sciences, with their diverse philosophical and methodological underpinnings.

Broadly speaking, a great deal of research aimed at understanding comanagement has tended to focus on and contribute toward the normative concepts that have come to characterize the field. These studies have been invaluable in developing a general relational picture of comanagement and for theory building. On the other hand, far fewer studies have adopted a more critical stance. Those that have demonstrate the importance of taking into account casespecific histories and the role of power when attempting to understand situations that are significantly less technical than many analyses of commons governance might lead one to believe (Li 2006). However, despite the large and growing body of literature on the subject, Carlsson and Berkes (2005:72) observe that "our tools for conceptualizing and analyzing co-management are strikingly blunt."

Armitage (2008) has argued for a more inclusive approach that is capable of incorporating the normative concepts associated with governance arrangements such as (adaptive) comanagement within a framework that grounds them in the contextual details of a specific case. To this end, he suggests a fruitful synthesis could see commons and resilience discourses merge with concepts, methods, and approaches found in political ecology, including analyses of history, discourse, and the political economy. Wilson (2010) points out that when it comes to discussions of social resilience a tension often exists between systematic approaches that proceed upon normative lines, and more critical attempts that fail to achieve the same systematic rigor: "when [resilience] discussions are systematic they tend not to be critical, and when they are critical they fail to be systematic" (Wilson 2010:52). Similarly then, Wilson posits that it would be beneficial to combine resilience thinking with approaches developed in critical social theory and that are employed by those working within political ecology.

The challenge then is the development or adoption of a framework that is general and flexible enough to encompass the methodological diversity required to investigate the various 
dimensions of comanagement from both a normative and critical perspective, and detailed enough to ensure a systematic and structured analysis. Articulating this goal, Plummer and Armitage (2007a:841) state that "to further build and consolidate the theoretical foundations of co-management, it will be necessary to pursue methodologically consistent avenues of research across geographical locations and resource contexts. Systematic evaluation of experience grounded in commonly framed approaches will play a key role in this regard." We demonstrate how the politicized IAD Framework can be used to address this challenge.

\section{THE POLITICIZED IAD FRAMEWORK}

We provide an overview of the Institutional Analysis and Development (IAD) Framework, a key tool for scholars interested in how diverse governance systems affect people's ability to solve problems, as well as the modifications Clement (2010) has made to the framework in bringing explicit attention to the role of the political economy, discourse, and power in studies of natural resource management. We keep our discussion of the original IAD Framework to a minimum, and instead refer the reader to the many good summaries and expositions to be found in the literature (see for example Kiser and Ostrom 1982, Ostrom 1990, 2005, 2011, Ostrom et al. 1994, Blomquist and DeLeon 2011, McGinnis 2011).

\section{The IAD framework}

The Institutional Analysis and Development (IAD) Framework provides a means for inquiring into a subject by bringing explicit attention to the relevant variables and the questions one may want to ask (Blomquist and DeLeon 2011). At the heart of the framework is an "action arena," consisting of an "action situation," which is the social space where individuals or groups of individuals interact and outcomes are produced, and the "actor," which contains the theory of the individual that the analyst wishes to draw upon. Behavior of participants in the action situation is influenced by three sets of exogenous variables: the biophysical and material world, the community, and the rulesin-use (Fig. 1). According to McGinnis (2011:172), these variables "encompass all aspects of the social, cultural, institutional, and physical environment that set the context within which an action arena is situated."

The action situation can be further broken down into seven working components (Fig. 2) consisting of participants who take up various positions, where any given position allows the participant to undertake certain actions that are dependent on how much information they possess about each available action, how actions are linked to potential outcomes, the degree of control individuals exercise over these outcomes, and the costs and benefits they assign to them (Ostrom 1990). McGinnis (2011:173) observes that these working components of an action situation serve to "specify the nature of the relevant actors as well as the resources and options they face." The three exogenous variables are able to affect different parts of the action situation (Ostrom 2005). Furthermore, a key feature of the IAD Framework relates to its ability to analyze behavior at multiple theoretical levels by shifting from one action situation to deeper rule-changing situations (Kiser and Ostrom 1982). Three nested levels are commonly recognized: the operational, collectivechoice, and constitutional choice (Fig. 3). One of the main strengths of the IAD Framework lies in its ability to provide a structured and consistent approach to analyzing complex phenomena. It also recognizes the interdependency of the three exogenous variables. For example, the relevance of any set of rulesin-use depends strongly on the prevailing biophysical conditions and the shared norms and values of those for whom the rules are intended.

Fig. 1. The IAD Framework. Adapted from Ostrom (2005).

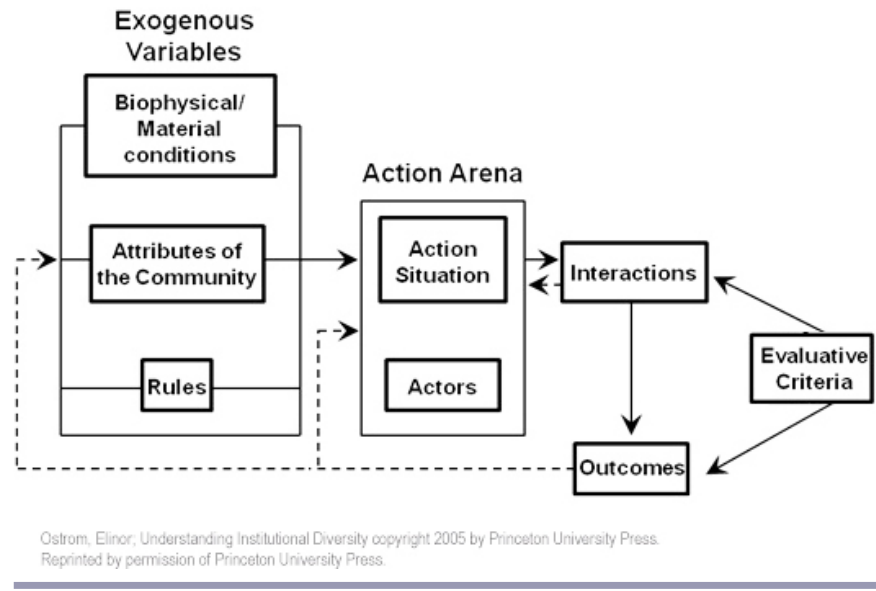

Fig. 2. The action situation of the IAD Framework. Adapted from Ostrom (2005).

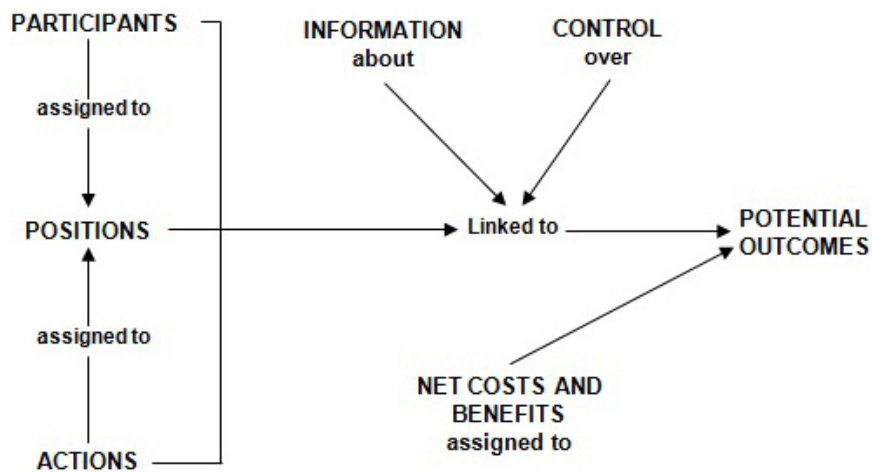

Ostrom, Elinor, Understanding Institutional Diversity oopyright 2005 by Princoton University Press Reprinted by permission of Princeton Uniwersity Press

The IAD Framework is compatible with a range of criteria that can be used to evaluate the process and outcomes related to the institutional arrangement under consideration. Ostrom (2005) lists as examples of criteria that are suitable for examining the overall performance of an institutional arrangement, (1) economic efficiency, (2) equity, (3) adaptability, resilience, and robustness, (4) accountability, and (5) conformance to general morality. Furthermore, Imperial (1999) discusses how the IAD Framework brings attention to three interrelated transaction costs that are associated with interorganizational policy implementation and that provide a suitable means for assessing an institutional arrangement 
at different points in time: information costs, coordination costs, and strategic costs. Ostrom (2005) observes that changing to a different institutional arrangement generally entails trade-offs between different sets of evaluative criteria, where the relative success of an arrangement will depend upon stated policy or other objectives.

Fig. 3. The linkages among rules and levels of analysis. Adapted from Ostrom (1990).

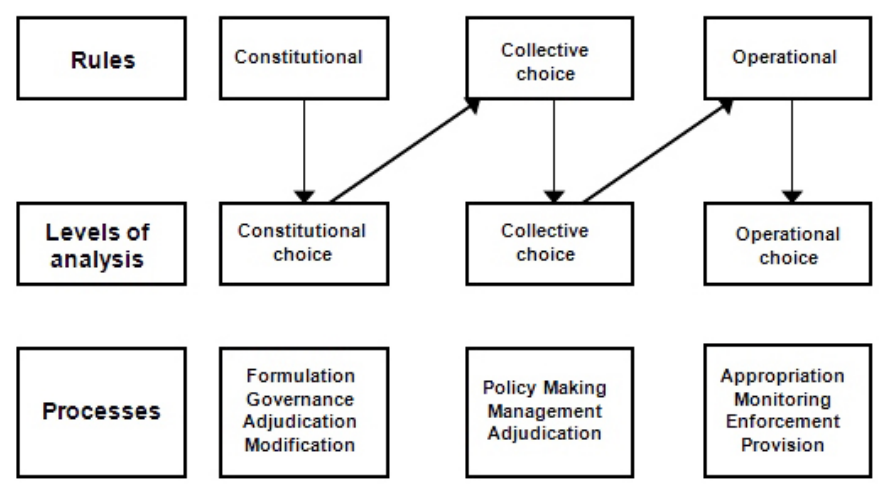

Enriching the framework

Despite its many strengths the IAD Framework, and commons theory more generally, has been criticized for being both ahistorical and apolitical (Agrawal and Yadama 1997, Mosse 1997, Agrawal 2002), giving too much precedence to rules and the way in which rules operate to mould and constrain human behavior, while failing to adequately account for power dynamics and context (Jentoft et al. 1998, Ribot et al. 2006). McCay (2002) points out that although commons theory does consider contextual variables such as group size or resource complexity, a real appreciation of context must extend beyond such variables to an awareness of what she calls "situation." According to McCay, accounting for the situations in which people make decisions and undertake actions requires an understanding of how rules and property rights emerge from within particular historical, ecological, and cultural traditions. As such, explaining how people relate to each other and to their environment "requires specification of those situations and their broader context" (McCay 2002:393), something the IAD Framework only partially addresses. Furthermore, scholars employing the IAD Framework generally posit that institutions emerge and develop as the result of rational or boundedly rational decision makers whose behavior relates to a set of incentives, and in so doing it they fail to adequately consider the power dynamics at work in a system of governance (Johnson 2004).

Responding to these criticisms, Clement (2010) has proposed an adapted version of the IAD Framework that considers the role of power and the wider historical processes that come to bear on an action situation. To do this, the new "politicized" IAD Framework explicitly recognizes the need to consider discourse and the influence of political and economic forces (Fig. 4). In so doing, Clement has answered calls for more normative approaches to understanding the commons to take advantage of critical methods employed by those working in the field of political ecology (McCay
2002, Armitage 2008, Wilson 2010). Although Clement has elaborated the rationale behind the revisions to the IAD Framework elsewhere (Clement and Amezaga 2009, Clement 2010), we focus on how power and the wider context have been incorporated into the IAD Framework by discussing the two additional variables proposed by Clement: "discourse" and the "political-economic" context. These variables affect both the "action situation," in particular the ways in which participants are positioned, as well as the "actors" component of the action arena, where they shape values, norms, and preferences (Clement 2010).

Fig. 4. The politicized IAD Framework, with the additional variables shaded in grey. Adapted from Clement (2010).

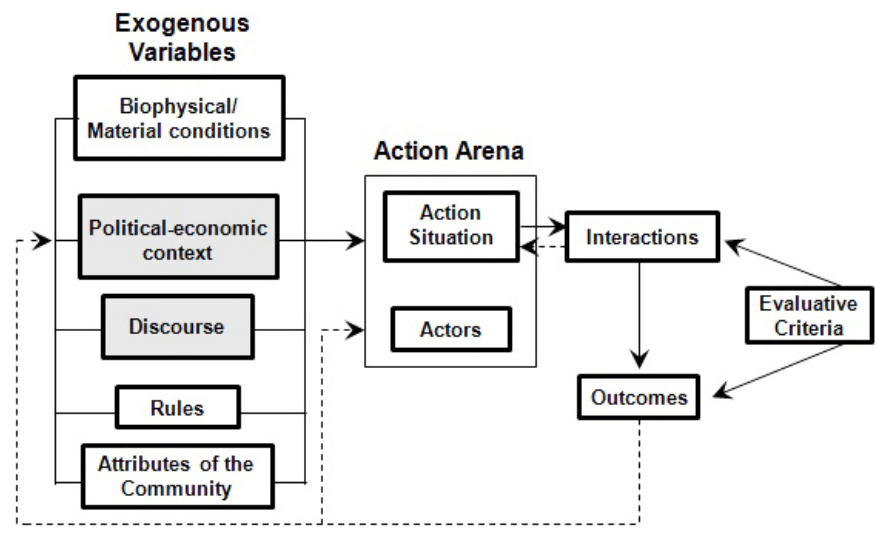

\section{Discourse}

Discourse is a term that can be construed in many ways. In everyday parlance the terms discourse and discussion are often considered to be synonymous (Taylor 2001). When analyzing discourse, however, the two terms must be distinguished from each other so that the discussion (or debate) becomes the focus of analysis, whereas discourse is understood to be a shared way of apprehending the world that is embedded in language and that "enables those who subscribe to it to interpret bits of information and put them together into coherent stories or accounts" (Dryzek 2005:9). Hajer and Versteeg (2005:175) define discourse as "an ensemble of ideas, concepts and categories through which meaning is given to social and physical phenomena, and which is produced and reproduced through an identifiable set of practices." Thus although an independent reality exists, we make sense of that reality and attribute meaning to it through the use of particular discourses. To this extent, discourse plays a fundamental role in the social construction of the world we inhabit. Ontologically, this perspective is associated with critical realism (Harré 1972, Bhaskar 1975) and provides a philosophical bridge between the natural sciences and more interpretive strands of the social sciences.

The inclusion of discourse into the IAD Framework brings with it a number of important developments. Of significance from an institutional perspective is the consideration of power. Although in the original IAD Framework Ostrom recognized power as a relevant factor, she nonetheless does so in a highly instrumental manner by taking the power of a participant in an action situation to be the range of outcomes they are able to affect multiplied by 
the control they exercise over these outcomes (Ostrom 2005). A far more dynamic conception of power can be found in the work of the social philosopher Michel Foucault, who considered power, knowledge, and discourse to be bound together. For Foucault, power "is not an institution, and not a structure; neither is it a certain strength we are endowed with; it is a name one attributes to the complex strategical situation in a particular society" (Foucault 1978:92). The power of social actors in this situation is relational, in which the various positions and functions are defined and negotiated through particular discourses (Hall 2001). Hajer (1995:49) notes therefore that "in this view the power of the institution is permanent in so far as it is a constant feature of the discourses through which the role of that institution is being reproduced." Thus discourses and institutions are intrinsically bound up in one another. Dryzek (2005:20) observes that certain discourses become embodied in institutions, where they "constitute the informal understandings that provide the context for social interaction, on a par with formal institutional rules."

Also of interest to our discussion of discourse and the IAD Framework is the notion of a "position." In the framework's action situation all participants are assigned positions (Fig. 2), in which the standing of a person in any given position relates to the authorized actions available to them in this position or the way in which the position they assume limits their actions. Positions are conceived of as "anonymous slots" into which participants can move, and may include judges, defendants, buyers, sellers, resource users, regulators, and so on (Ostrom 2005:41). This definition of a position is akin to what social psychologists have traditionally termed a "role." In critiquing the static and largely formal concept of role as a way of understanding the self in social interactions, Davies and Harré (1990) have instead proposed that people actively position themselves and those they are interacting with in a situation by employing ideas, concepts, and categories that derive from particular discourses or that relate to particular storylines that actors draw upon in making sense of the world. Thus positioning theory invokes a far more dynamic understanding of social encounters in which people are involved in an argumentative exchange, and identity is continually negotiated as actors attempt to position themselves and others, often subconsciously, in relation to a particular issue or set of issues.

\section{Political-economic context}

The political-economic variable in the politicized IAD Framework draws the analyst's attention to contextual factors that not only require one's analysis to expand outward to take account of the wider political and economic factors that directly or indirectly influence the behavior of participants in the action situation, but also to expand backward in time so as to understand the events and processes that have given rise to present-day conditions. As with discourse analysis, this approach resonates strongly with the field of political ecology in which politicaleconomic analyses hold a central position. For these scholars, "a focus on the respective roles and interactions of the state and the market and the influence on environmental outcomes is critical" (Neumann 2005:6). Without an understanding of both the local and wider political and economic situation it is not possible to appreciate the distribution of power among social actors, and how such a power dynamic affects the behavior of individuals. The consideration of political and economic factors also draws attention to the issue of scale by acknowledging that "the design and sound implementation of adequate rules at the local level is significantly constrained by decisions made at higher governance levels and by the structure of the economy" (Clement 2010:137). According to Agrawal and Yadama (1997), explicit inclusion of the political-economic context is a necessary addition to mainstream commons research that has tended to focus on local communities without regard for political and economic forces and the ways in which they structure interactions within and between groups and organizations.

What's more, despite the fact that institutional design is historically contingent or "path dependent," work on the commons has tended to be remarkably ahistorical (Stern et al. 2002). However, appreciation of how the political-economic context structures power dynamics in a system requires one to consider not only present-day conditions but also the activity leading up to them. Mosse (1997:470) has therefore argued that historical analyses must be incorporated into standard models of community resource management on the grounds that "historically-specific structures of power, rather than simply calculated pay-offs (or traditional wisdom) underlie the norms and conventions of collective resource use, and account for the occurrence and persistence of local institutions of resource use. These do not only manage resources, they also serve to reproduce relations of dominance and dependence, and provide the context for political strategy and status competition."

In concluding then, although the original IAD Framework has many strengths, not least of all its analytical clarity, applicability, and capacity to account for nested levels of decision making, its insights have failed to include critical approaches that recognize that "the interplay of power, the positioning of various actors within nested hierarchies and the role of context all exert a powerful influence" (Armitage 2008:24). The two variables Clement (2010) has included in the IAD Framework develop this critical dimension by drawing attention to the significance of the discursive and political-economic context in which individuals, groups, and systems of resource governance are embedded and in so doing bring an added awareness of "situation" to the analysis, as argued for by McCay (2002). Before proceeding, it must be noted that the IAD Framework has subsequently been modified by Ostrom and her colleagues so as to develop a more complex framework for analyzing social-ecological systems (SES), where the emphasis has been on unpacking the "biophysical" variable of the original IAD Framework (Ostrom 2007, 2011). Although this emerging SES Framework promises much, we are instead interested only in the politicized IAD Framework proposed by Clement (2010) because of its applicability to analyses of (adaptive) comanagement.

\section{APPLYING THE FRAMEWORK TO (ADAPTIVE) COMANAGEMENT}

We discuss how the politicized IAD Framework is well suited to "a systematic evaluation of [the comanagement] experience grounded in commonly framed approaches" (Plummer and Armitage 2007a:841). One of the great strengths of the framework derives from its ability to bring all the relevant factors of a situation to the attention of the analyst. Although not all of the five exogenous variables previously discussed will necessarily carry the same weight from one study to the next, the politicized 
IAD Framework nonetheless ensures that each is considered and that those variables that play an important role in the behavior of the situation under consideration are not overlooked. Similarly, though the various components of the action situation (Fig. 2) highlight the basic elements that must be incorporated into an analysis of the interactions between actors in any situation, it can also serve to guide an investigation into specific aspects of that situation, such as the ability for certain individuals or groups to participate in decision making, the ways in which actors position themselves and others, the values they attribute to particular outcomes that can be achieved, and so forth.

In keeping with those writers who have argued that understanding comanagement more fully will require the incorporation of both normative and critical methods of analysis, we shall discuss how the politicized IAD Framework can be used to analyze the various dimensions of comanagement as outlined previously. Given the methodological breadth on offer to users of the politicized IAD Framework, the many interests of scholars working in the field of comanagement, and the many different elements and components that have come to be associated with the term itself (see Plummer and Fitzgibbon 2004, Plummer 2009), the intention here is not to provide an exhaustive account of the ways in which the framework can be employed to investigate comanagement. Instead the discussion is intended to be suggestive; to point to the relationship between the framework and comanagement while demonstrating a logical progression someone attempting to undertake a comprehensive comanagement study may wish to follow. In Table 1 we provide a generalized account of the relationship between comanagement and the politicized IAD Framework.

The first step an analyst takes when employing the politicized IAD Framework is to define the action situation (Fig. 2). In considering comanagement, one may be interested in such instances as a government organization and a community of resource users, a geographical area, or a particular resource. Given Carlsson and Berkes' (2005) argument that comanagement should be studied in terms of function and process, we follow them in suggesting a good option for defining the action situation is to start with the management activities associated with the resource in question and the actors whose job it is to carry them out. In doing so it may be useful to consider the seven broad management activities comanagement can enhance, as outlined by Pinkerton (1989b:6). Thus although the resource, be it a region of forest or a river corridor, is geographically located, the action situation may include actors located outside of the resource boundary if their decisions affect the management of that resource (Imperial 1999).

Defining the action situation according to management activities, or function, emphasizes the importance of scale by bringing attention to the organizational levels across which management decisions are located. This is significant to analyses of comanagement because of its focus on cross-scale interplay (Pomeroy and Berkes 1997, Carlsson and Berkes 2005, Berkes 2009), and where it has been recognized that "the connections between governmental and nongovernmental actors themselves are ripe for examination using IAD" (Blomquist and DeLeon 2011:5). Furthermore, by ascertaining who the relevant actors involved in a given management activity are, and the relationship of these actors to one another in the action situation, the framework allows the researcher to develop a network approach to analyzing process and function, a line of enquiry that is currently receiving much attention and that serves to promote an understanding of "comanagement as governance" (Carlsson and Berkes 2005, Newman and Dale 2005, Bodin et al. 2006, Janssen et al. 2006). The politicized IAD Framework can then be used to critically analyze the connections and interactions within these networks and the outcomes that occur as a result, including processes of problem solving, social learning, power sharing, and the development of trust and newly devised rules-in-use. The framework can also be used to investigate how a particular network "is embedded in a system of political economy, and embedded in greater cultural or normative systems" (Brown 2001:2, as cited in Plummer and Fitzgibbon 2007). In the end, whichever way the action situation is defined, what is important is to appreciate that in many respects comanagement is concerned with the participation of actors at the collective-choice level (Pinkerton 2003) because this is where management decisions take place (Ostrom 1990, Schlager and Ostrom 1992).

Having decided upon the action situation, a general strategy is then to identify which aspects of the biophysical, politicaleconomic, discursive, institutional, and community setting influence the various elements of the action situation as detailed in Figure 2. In effect, how do the exogenous variables affect who is allowed to participate in the situation, what actions they can take and the costs associated with them, what outcomes they can affect, how actions are linked to outcomes, what information they have access to, and the extent to which they have control over outcomes they can affect (Ostrom 1990). To do this, one may first wish to enquire into the biophysical conditions by considering the characteristics of the resource. Here commons scholars have identified particular resource attributes, such as complexity, size, and productivity that affect the likelihood that resource users will self-organize (Ostrom 1999b, 2009). Self-organization is also a concept that is considered important in both resilience thinking, where the focus is on how systems reorganize in the face of change, and political ecology, where the interest is in understanding how environmental systems can form or shape self-organizing, selfsustaining power relationships (Armitage 2008). Furthermore, self-organization may connote institution building as rules are crafted to structure new forms of collective action between participants (Pinkerton 1999, Hodgson 2006). Another important aspect of the biophysical conditions relates to the presence of technology in the system of interest. For example, Pahl-Wostl et al. (2007) observe that large, centrally designed infrastructure is indicative of single sources of design, power, and delivery, that is, system attributes that characterize a commandand-control approach to resource governance. Alternatively, technology on an appropriate scale is typical of diverse sources of design, power, and delivery and may therefore represent a system that is better primed for more pluralistic forms of decision making such as comanagement.

Analysis of the political-economic context reveals ways in which power is distributed among the actors in a management arrangement and provides a critical appreciation of the potential for concepts such as trust or power sharing to emerge and develop. For example, in questioning the fact that "virtually every comanagement case study encountered in the literature [on the circumpolar North] is a success story," Nadasdy (2003a:368) 
Table 1. Relationship between the politicised IAD Framework and (adaptive) comanagement.

\begin{tabular}{ll}
\hline \hline Exogenous Variable & Description of Variable \\
\hline Biophysical and & $\begin{array}{l}\text { Ecosystem conditions, resource attributes, an } \\
\text { forms of technology. In the action situation } \\
\text { this variable affects what actions are possible, } \\
\text { what outcomes can be produced, and what is } \\
\text { contained in the actors' information sets. }\end{array}$ \\
Political-economic & $\begin{array}{l}\text { A contextual variable concerned with the } \\
\text { overall political economy of the system in } \\
\text { which the action situation is embedded. In } \\
\text { particular this variable positions participants } \\
\text { in the action situation, and shapes their } \\
\text { values, norms, and preferences. It strongly } \\
\text { influences the distribution of power between } \\
\text { stakeholders. }\end{array}$
\end{tabular}

Discourses Gives meaning to the physical and social world, and can be used to sustain or challenge existing power structures. In particular this variable positions participants in the action situation, and shapes their values, norms, and preferences.

Rules-in-use

Attributes of Community
Relationship of Variable to (Adaptive) Comanagement

Environmental feedback caused by changes in ecosystem or resource dynamics can trigger collective action, where certain properties of the resource and the presence of technology are known to affect the ability of actors to self-organize. Particular forms of infrastructure, e.g., large and centralized or decentralized on an appropriate scale, are also indicative of the type of governance arrangement, e.g., top-down or polycentric, and thus the potential for comanagement to emerge.

Comanagement networks are embedded in the wider political economy, which shapes power relations, structures cross-scale interplay and network characteristics, and influences the forms of power sharing, trust building, and rule crafting that emerge. These attributes in turn affect processes of problem solving and social learning. The structural influences of the political economy do not affect local environmental conditions directly but are mediated through the institutions and organizational characteristics of the comanagement arrangement in question. The political economy is a "slow variable" that strongly shapes overall system trajectory.

Environmental crises, which often serve as a trigger for comanagement, are not an objectively definable state of the world but instead are constructed and negotiated by stakeholders through the use of particular discourses. Discourses also operate to sustain or challenge power relations between participants as certain discourses become normalized or are undermined, and by positioning the actors in the action situation according to particular storylines. They are also vital for developing and maintaining the institutions that enhance collaborative and learning-based approaches. Discourses therefore provide a critical approach to understanding power-sharing arrangements between participants in the comanagement process.

Rules can operate to make a system of resource governance rigid and vulnerable to change, or flexible and dynamic by facilitating communication, negotiation, conflict resolution, problem solving, and joint learning within and between scales of organization. Enabling legislation at higher levels can encourage selforganization and the process of adaptive comanagement, while locally devised rules can enhance social learning, tighten environmental feedback loops, and increase the adaptive capacity of resource users. Rule changing allows participants to alter a system's trajectory and to institutionalize social memory. Physical attributes of the community affect the ability of stakeholders to selforganize; for example, the size of a group alters stakeholders' incentives to act collectively, and differences in race and gender may affect power relations and levels of trust between participants. Particular functions of individuals, including acting as leaders, knowledge carriers, or networkers, are known to affect the process of adaptive comanagement. Furthermore, cultural differences or similarities can greatly influence the ability of a comanagement arrangement to emerge by undermining or enhancing trust and social capital, and the ability of participants to communicate, jointly learn about, and act in response to changes in social or environmental circumstances. This variable also allows the analyst to explore the relationship between comanagement networks and the larger cultural systems in which they are embedded. critically examines the case of a comanagement sheep-steering committee in southwest Yukon and shows that despite the fact that this particular case has been branded a model of success by many, the indigenous Kluane First Nation members and some of the biologists on the comanagement committee considered the process to be a "complete failure." Nadasdy demonstrates that although there are a number of contributing factors that led to this outcome, the roots of the problem are in fact political and in the end the comanagement process only served to reinforce existing power imbalances between the various parties. In a separate analysis on forest use in the Kumaon Himalaya in India, Agrawal and Yadama (1997) argue that socioeconomic forces can significantly influence the condition of renewable resources and the ways in which these resources are managed. However, the authors discuss how such forces are always mediated by local institutions; findings that they conclude have significant implications for the role of comanagement between the market, state, and the community. Adger et al. (2006) also highlight the importance of considering the political-economic variable in the politicized IAD Framework through a discussion of how the structure of the political economy, which reflects the distribution of power between stakeholders, strongly influences cross-scale interactions in comanagement networks. Here "cross-scale interactions by powerful stakeholders have the potential to undermine trust in resource management arrangements," where "the structure of cross-scale interplay, in terms of relative winners and losers, determines its contribution to the resilience of socialecological systems" (Adger et al. 2006:9).

Understanding political and economic events and how they have come to structure the action situation draws attention to the evolutionary nature of the process. Graham and Ernstson (2012) 
show how an historical analysis of a comanagement agreement in Macassar Dunes, Cape Town, reveals that the political approach that characterized decision making prior to the introduction of the comanagement arrangement tended to be top down and exclusionary. The authors conclude that "the formative stages of the co-management process represent a fundamental co-management barrier for some interviewees, and have implications in the contemporary setting for who should now 'take responsibility."' Thus an historical account of political and economic drivers provides an insight into the factors that have come to determine the current system trajectory as well as those factors that may constrain or enable the pathway it takes in the future. Here again then, a critical perspective unearths contextual details pertaining to core concepts in resilience thinking and adaptive comanagement, in this case "system trajectory" and "pathways of change," therefore grounding abstract theoretical constructs within the specifics of a particular study.

Discourse analysis offers up many fruitful avenues of enquiry for the study of comanagement. For example, Degnbol (2003) draws attention to the gap between mainstream discourses in fisheries science and the discourses of local users. He argues that if comanagement arrangements are to become truly inclusive this gap must be bridged. It is therefore of interest to the researcher to understand the different ways in which users and government officials talk about the resource system in question, including its use and its management. Alternatively, examining the ways in which the various actors in the comanagement process talk about each other can also provide valuable insights into issues such as trust, power sharing, problem solving, and social learning. In discussing an agreement to comanage shellfish in the Dutch Wadden Sea, Steins (1999:139) reveals how the imagery participants draw upon in describing the character and activity of the other actors in the agreement has tended to "cloud the discussions over resource use in the negotiating and decisionmaking process at the collective-choice and constitutional level."

Discourse analysis therefore provides a means of understanding how participants in a comanagement arrangement draw upon particular discourses and storylines to position themselves and others in relation to the challenge of resource management, and the developments that occur as these positions are negotiated and renegotiated over time. An inherent feature of such analyses are the power dynamics operating within and across nested scales of organization, be it relating to the link between humans and their environment or between networks of actors in a collaborative setting. Therefore although power sharing is often portrayed as an outcome in the literature, the framework also highlights how the balance of power between participants in the action situation intrinsically influences their behavior and the sorts of outcomes that can be achieved, including the degree to which an equitable power-sharing arrangement may feasibly be reached. Furthermore, understanding how an environmental issue becomes a crisis through the meanings attributed to it by social actors is also important because a precondition for comanagement is the recognition of a crisis of some sort (Pinkerton 1989b, Selin and Chavez 1995, Plummer and Fitzgibbon 2004). The point at which an environmental issue is deemed to be a crisis is not an objectively defined state of the world but instead emerges as a result of the ways in which the problem is discursively constructed and particular storylines are employed to make sense of the many competing discourses different actors bring to the issue, be they government officials, scientists, resource users, citizens, or whoever (Hajer 1995).

Analysis of the rules-in-use provides an understanding of the incentives an individual or group face in a given action situation. Actors make decisions within a system of rules and appreciating how such rules constrain or enable a comanagement arrangement is therefore of much importance to the analyst, where changes in the rules toward a more inclusive system of governance reflects a process of institution building for comanagement (Pomeroy and Berkes 1997). Such changes may take the form of wider enabling legislation that recognizes a community of resource users as legitimate participants in particular arenas of management decision making and that is known to encourage self-organization and the emergence of adaptive comanagement (Olsson et al. $2004 a$ ), or alternatively rules might be crafted that aim to facilitate collective action between resource users at the local level or between local institutions and government bodies (Ostrom 1990, $1999 \mathrm{~b}$ ). In their process-oriented model of comanagement, Borrini-Feyerabend et al. (2000) discuss how before entering a learning-by-doing phase, rules must be devised that allow participants to enter into negotiation and discussion with one another. Identifying barriers or opportunities to rule changes such as these requires an understanding of the system's trajectory and the power dynamics at play, which comes about through a critical analysis of the political-economic and discursive landscape.

The final variable available to the analyst relates to the community within which the action situation is located. In many ways this variable represents the cultural dimension of the analysis, and can prove an especially significant feature of attempts to comanage a resource because in many cases comanagement arrangements have emerged from the coming together of disparate cultural perspectives. Sometimes the difference may lie between the organizational culture of a bureaucratic government administration whose guiding principles are predicated upon a rational scientific tradition and the indigenous value-system of a community of resource users (Castro and Nielsen 2001, Nadasdy $2003 b$ ). At other times the differences may be less pronounced but perhaps still challenging if the political culture in the country reflects a tradition of nonparticipation from citizens, leans heavily toward a different form of governance such as market rationalism, or favors some kinds of comanagement arrangements over others (Sen and Nielsen 1996). Ostrom (2005:27) makes clear the importance of considering the cultural aspect of the comanagement process when she states that "if the participants in a situation come from many different cultures, speak different languages, and are distrustful of one another, the costs of devising and sustaining effective rules are substantially increased." However, the variable "community" need not refer only to a consideration of culture but may relate to other attributes, such as the size and composition of a community of resource users, the race, gender, and age of participants, or the degree of inequality in the distribution of basic assets among the participants (Ostrom 2005). From an adaptive comanagement perspective, the analyst may also benefit from thinking about the key functions that participants perform in the action situation, where these functions include leaders, followers, knowledge carriers, networkers, innovators, interpreters, and entrepreneurs, and how the prevalence, distribution, and relationship between 
the various individuals performing such functions affects the development of the comanagement process (Folke et al. 2005, Berkes 2009, Plummer 2009).

Thus each variable associated with the politicized IAD Framework in turn relates to a suite of questions that are of relevance to the study of comanagement. What variables and which questions emerge as the focus of any given study will depend upon their relevance to the case under consideration and the interests of the researcher. However, by bringing attention to all the relevant exogenous variables that affect an action situation and the components that comprise it, the framework ensures that an analyst identifies those aspects of the situation that are most relevant to the objectives of their study and ensures that no critical element is overlooked. Furthermore, the framework is also well placed to structure cross-disciplinary team studies, in which the analytical clarity it provides can be used to guide and organize the work threads of the various members in the team. Having conducted the analysis, the researcher may be in a position to make predictions as to the outcomes of the comanagement process. However, given the large degree of uncertainty and procedural openness usually associated with comanagement, it is unlikely that any attempt at making predictions can move beyond informed estimations of what is more or less likely to occur in a particular situation, or a general appreciation of what the consequences of changing the rules would be (Ostrom 2005).

Alternatively, the analyst may wish to evaluate the outcomes that have transpired as a result of the comanagement process. As discussed previously, transaction-cost analysis provides a means of evaluating the performance of an interorganizational network at different junctures in time, by considering information costs, coordination costs, and strategic costs (Imperial 1999). The advantage of this kind of assessment is that no bias exists concerning the appropriate form of governance for a given situation. Thus it may be that comanagement proves to be inappropriate or that another governance arrangement is better suited to the particulars of the case. Furthermore, when crafting a new institutional arrangement, it may be common for one set of transaction costs to decrease and another to rise. For example, in the early stages of the comanagement process one may observe an increase in coordination costs as a greater number of participants become involved in decision making and new procedures to which they are not accustomed. However, over time, information costs may decrease as levels of communication improve, decision making becomes routine, and information asymmetries between the various actors become less pronounced. Thus transaction costs can be divided up according to whether they are long-term or short-term by nature (Carlsson and Berkes 2005).

Beyond the analysis of transaction costs, one may also wish to evaluate the overall performance of the system after a sustained period of time. Although many evaluative criteria are compatible with the politicized IAD Framework, some are more relevant to comanagement than others. For example, improving equity has always been one of the central premises for implementing comanagement (Pinkerton 1989a, Ingles et al. 1999, Plummer and Fitzgibbon 2004). Here a distinction must be made between equity relating to (1) the proportionality between what an individual pays and the benefits they receive (fiscal equivalence), and (2) a system based on an individual's ability to pay (redistributional equity; Ostrom 2005), where the relative weight placed on either of these two forms of equity will be case specific. With the adaptive turn in comanagement, attention must also be given to the resilience of the system. Ostrom (2005:67) raises such questions as "do individuals learn from experience within an action situation?" and "Do they adapt to new circumstances as they arise or do they become rigid in their response over time?" More recently, Plummer and Armitage (2007b) have proposed a comprehensive resilience-based framework for evaluating adaptive comanagement, in which they have developed scalespecific parameters for three broad categories of assessment criteria: ecosystem conditions, livelihood outcomes, and process and institutional conditions. The framework they provide emerges from a complex adaptive systems perspective and offers a systematic means for assessing adaptive comanagement in accordance with the various elements that have come to define it.

In summary, this discussion has demonstrated that the politicized IAD Framework is a useful tool for guiding analyses and evaluations of (adaptive) comanagement according to an integrated methodological approach. By referring to particular examples from the literature, we have shown how the five exogenous variables of the framework draw attention to the various faces of comanagement as outlined by Berkes $(2007,2009)$ and emerging concepts from resilience thinking and political ecology such as scale, self-organization, path dependence, and system trajectory (Olsson et al. 2004b, Folke et al. 2005, Neumann 2005). At the same time, the variables permit the analyst to ground these concepts in a critical awareness of "situation" (McCay 2002). Furthermore, by considering rules-in-use, aspects of the political-economic context, and evaluative criteria such as transaction costs and efficiency, the politicized IAD Framework remains relevant to policy makers through the identification of the socioeconomic the institutional components of an action situation. Thus the framework overcomes perceived weaknesses of approaches in political ecology that have been criticized for failing to produce useful policy recommendations (Neumann 2005), an issue that has also been recognized as a challenge for adaptive comanagement scholars (Armitage et al. 2007).

\section{CONCLUSION}

We have proposed that Clement's (2010) "politicized" version of the Institutional Analysis and Development (IAD) Framework is well suited to the study of (adaptive) comanagement. In doing so we have answered calls from scholars to develop or adopt a common framework that facilitates a systematic study of comanagement across different settings and that is able to ground the normative concepts associated with the subject in critical approaches that recognize context and the power dynamics at play in a system of resource governance. Over the last three decades comanagement theory has come to be seen in a number of different ways. The general tendency has been to move from a perspective that views comanagement in terms of a formal powersharing arrangement between a homogenous government and a community of resource users, to a focus on function, process, and the appreciation that social-ecological systems are complex, adaptive, and characterized by an inherent degree of uncertainty. Thus comanagement has "many faces" and can be thought of in terms of power sharing, institution building, trust building, process, problem solving, social learning, and governance (Berkes 2007, 2009, Plummer and Armitage 2007a). 
We have shown how the politicized IAD Framework is an appropriate tool for guiding an analysis of the many faces of comanagement by drawing attention to the various dimensions of the process and the sorts of questions that arise when considering them. The framework is also unbiased in that it does not favor one form of governance, such as comanagement, over another but instead evaluates each situation on its own merits (Imperial 1999). Thus the framework serves as a point of crosspollination between the field of comanagement and scholars working in other areas of environmental governance by providing a consistent means of analyzing and evaluating the many institutional arrangements that exist across differing geographical and social contexts. At the same time, the politicized IAD Framework provides the specificity and structure needed to conduct a comprehensive analysis of comanagement, one that critically assesses the potential for normative concepts such as power sharing, trust, and social learning to emerge from within the biophysical, political-economic, discursive, institutional, and cultural milieu of a particular study. Such analyses provide a solid foundation upon which to make sound policy recommendations.

Responses to this article can be read online at: http://www.ecologyandsociety.org/issues/responses. $\mathrm{php} / 6177$

\section{Acknowledgments:}

The authors gratefully acknowledge the funding provided by the Engineering and Physical Science Research Council (EPSRC). This research is part of the EPSRC funded project Transforming Water Scarcity Through Trading (TWSTT)-project reference EPI J005274/1. We would also like to thank Dr Heather Smith for her helpful comments.

\section{LITERATURE CITED}

Adger, W. N., K. Brown, and E. L. Tompkins. 2006. The political economy of cross-scale networks in resource co-management. Ecology and Society 10(2): 9. [online] URL: http://www. ecologyandsociety.org/vol10/iss2/art9/

Agrawal, A. 2002. Common resources and institutional sustainability. Pages 41-86 in E. Ostrom, T. Dietz, N. Dolsak, P. C. Stern, S. Stonich, and E. U. Weber, editors. The drama of the commons. National Academy Press, Washington, D.C., USA.

Agrawal, A., and G. Yadama. 1997. How do local institutions mediate market and population pressures on resources? Forest Panchayats in Kumaon, India. Development and Change 28 (3):435-465. http://dx.doi.org/10.1111/1467-7660.00050

Armitage, D. 2008. Governance and the commons in a multi-level world. International Journal of the Commons 2:7-32.

Armitage, D., F. Berkes, and N. Doubleday, editors. 2007. Adaptive co-management: collaboration, learning, and multi-level governance. University of British Columbia Press, Vancouver, British Columbia, Canada.

Armitage, D., M. Marschke, and R. Plummer. 2008. Adaptive comanagement and the paradox of learning. Global Environmental Change 18:86-98. http://dx.doi.org/10.1016/j.gloenvcha.2007.07.002
Armitage, D., R. Plummer, F. Berkes, R. I. Arthur, A. T. Charles, I. J. Davidson-Hunt, A. P. Diduck, N. C. Doubleday, D. S. Johnson, M. Marschke, P. McConney, E. W. Pinkerton, and E. K. Wollenberg. 2009. Adaptive co-management for socialecological complexity. Frontiers in Ecology and the Environment 7(2):95-102. http://dx.doi.org/10.1890/070089

Berkes, F. 2007. Adaptive co-management and complexity: exploring the many faces of co-management. Pages 19-37 in D. Armitage, F. Berkes, and N. Doubleday, editors. Adaptive comanagement: collaboration, learning, and multi-level governance. University of British Columbia Press, Vancouver, British Columbia, Canada.

Berkes, F. 2009. Evolution of co-management: role of knowledge generation, bridging organizations and social learning. Journal of Environmental Management 90(5):1692-702. http://dx.doi. org/10.1016/j.jenvman.2008.12.001

Berkes, F., P. George, and R. Preston. 1991. Co-management: the evolution of the theory and practice of joint administration of living resources. Alternatives 18:12-18.

Bhaskar, R. 1975. A realist theory of science. Harvester Press, Sussex, UK.

Blomquist, W., and P. DeLeon. 2011. The design and promise of the institutional analysis and development framework. Policy Studies Journal 39:1-6. http://dx.doi.org/10.1111/j.1541-0072.2011.00402. $\underline{\mathrm{X}}$

Bodin, Ö., B. Crona, and H. Ernstson. 2006. Social networks in natural resource management: what is there to learn from a structural perspective? Ecology and Society 11(2): r2. [online] URL: http://www.ecologyandsociety.org/vol11/iss2/resp2/

Borrini-Feyerabend, G., M. T. Farvar, J. C. Nguinguiri, and V. A. Ndangang. 2000. Co-management of natural resources: organising, negotiating and learning by doing. Kasparek Verlag, Heidelberg, Germany.

Carlsson, L., and F. Berkes. 2005. Co-management: concepts and methodological implications. Journal of Environmental Management 75:65-76. http://dx.doi.org/10.1016/j.jenvman.2004.11.008

Castro, A. P., and E. Nielsen. 2001. Indigenous people and comanagement: implications for conflict management. Environmental Science and Policy 4:229-239. http://dx.doi.org/10.1016/ $\underline{\text { S1462-9011(01)00022-3 }}$

Clement, F. 2010. Analysing decentralised natural resource governance: proposition for a "politicised" institutional analysis and development framework. Policy Sciences 43(2):129-156. http://dx.doi.org/10.1007/s11077-009-9100-8

Clement, F., and J. M. Amezaga. 2009. Afforestation and forestry land allocation in northern Vietnam: analysing the gap between policy intentions and outcomes. Land Use Policy 26(2):458-470. http://dx.doi.org/10.1016/j.landusepol.2008.06.003

Daniels, S. E., and G. B. Walker. 1996. Collaborative learning: improving public deliberation in ecosystem-based management. Environmental Impact Assessment Review 16:71-102. http://dx. doi.org/10.1016/0195-9255(96)00003-0 
Davies, B., and R. Harré. 1990. Positioning: the discursive construction of selves. Journal for the Theory of Social Behaviour 20:43-63. http://dx.doi.org/10.1111/j.1468-5914.1990.tb00174.x

Degnbol, P. 2003. Science and the user perspective: the gap comanagement must address. Pages 31-49 in D. C. Wilson, J. R. Nielsen, and P. Degnbol, editors. The fisheries co-management experience: accomplishments, challenges and experiences. Kluwer Academic, Dordrecht, The Netherlands. http://dx.doi. org/10.1007/978-94-017-3323-6 3

de Loë, R. C., R. Plummer, D. Armitage, S. Davidson, and L. Moraru. 2009. From government to governance: a state-of-the-art review of environmental governance. Final Report. Pre- pared for Alberta Environment, Environmental Stewardship, Environmental Relations. Rob de Loë Consulting Services, Guelph, Ontario, Canada.

Dryzek, J. S. 2005. The politics of the Earth: environmental discourses. Second edition. Oxford University Press, Oxford, UK.

Folke, C. 2006. Resilience: the emergence of a perspective for social-ecological systems analyses. Global Environmental Change 16(3):253-267. http://dx.doi.org/10.1016/j.gloenvcha.2006.04.002

Folke, C., T. Hahn, P. Olsson, and J. Norberg. 2005. Adaptive governance of social-ecological systems. Annual Review of Environment and Resources 30:441-473. http://dx.doi.org/10.1146/ annurev.energy.30.050504.144511

Foucault, M. 1978. A history of sexuality. Volume 1: an introduction. Random House, New York, New York, USA.

Glasbergen, P. 1998. The question of environmental governance. Pages 1-18 in P. Glasbergen, editor. Co-operative environmental governance: public-private agreements as a policy strategy. Kluwer Academic, Dordrecht, The Netherlands. http://dx.doi. org/10.1007/978-94-011-5143-6 1

Graham, M., and H. Ernstson. 2012. Comanagement at the fringes: examining stakeholder perspectives at Macassar Dunes, Cape Town, South Africa-at the intersection of high biodiversity, urban poverty, and inequality. Ecology and Society 17(3): 34. http://dx.doi.org/10.5751/ES-04887-170334

Hajer, M. 1995. The politics of environmental discourse: ecological modernization and the policy process. Oxford University Press, Oxford, UK.

Hajer, M., and W. Versteeg. 2005. A decade of discourse analysis of environmental politics: achievements, challenges, perspectives. Journal of Environmental Policy and Planning 7(3):175-184. http:// dx.doi.org/10.1080/15239080500339646

Hall, S. 2001. Foucault: power, knowledge, and discourse. Pages 72-81 in M. Wetherell, S. Taylor, and S. J. Yates, editors. Discourse theory and practice: a reader. Sage, London, UK.

Harré, R. 1972. The philosophies of science. Oxford University Press, Oxford, UK.

Hodgson, G. M. 2006. What are institutions? Journal of Economic Issues XL:1-25.

Holling, C. S. 1978. Adaptive environmental management and assessment. Wiley, London, UK.
Holling, C. S., and G. K. Meffet. 1996. Command and control and the pathology of natural resource management. Conservation Biology 10(2):328-337. http://dx.doi.org/10.1046/ j.1523-1739.1996.10020328.x

Imperial, M. T. 1999. Institutional analysis and ecosystem-based management: the institutional analysis and development framework. Environmental Management 24(4):449-465. http://dx. doi.org/10.1007/s002679900246

Imperial, M. T., and T. Yandle. 2005. Taking institutions seriously: using the IAD Framework to analyze fisheries policy. Society \& Natural Resources 18:493-509. http://dx.doi. org/10.1080/08941920590947922

Ingles, A. W., A. Musch, and H. Qwist-Hoffman. 1999. The participatory process for supporting collaborative management of natural resources: an overview. Food and Agriculture Organization of the United Nations, Rome, Italy.

Janssen, M. A., Ö. Bodin, J. M. Anderies, T. Elmqvist, H. Ernstson, R. R. J. McAllister, P. Olsson, and P. Ryan. 2006. Toward a network perspective of the study of resilience in socialecological systems. Ecology and Society 11(1): 15. [online] URL: http://www.ecologyandsociety.org/vol11/iss1/art15/

Jentoft, S. 1989. Fisheries co-management: delegating government responsibility to fishermen's organizations. Marine Policy 13(2):137-154. http://dx.doi.org/10.1016/0308-597X(89) 90004-3

Jentoft, S., B. J. McCay, and D. C. Wilson. 1998. Social theory and fisheries co-management. Marine Policy 22(4-5):423-436. http://dx.doi.org/10.1016/S0308-597X(97)00040-7

Johnson, C. 2004. Uncommon ground: the "poverty of history" in common property discourse. Development and Change 35 (3):407-434. http://dx.doi.org/10.1111/j.1467-7660.2004.00359.x

Kearney, J. 1984. The transformation of the Bay of Fundy herring fisheries, 1976-1978: an experiment in fishermen-government comanagement. Pages 165-203 in C. Lamson, editor. Atlantic fisheries and coastal communities: fisheries decision-making case studies. Dalhousie Ocean Studies Programme, Halifax, Nova Scotia, Canada.

Kiser, L. L., and E. Ostrom. 1982. The three worlds of action: a metatheoretical synthesis of institutional approaches. Pages 179-222 in E. Ostrom, editor. Strategies of political enquiry. Sage, Beverly Hills, California, USA.

Leach, W. D., and N. W. Pelkey. 2001. Making watershed partnerships work: a review of the empirical literature. Journal of Water Resources Planning and Management 127(6):378-385. http://dx.doi.org/10.1061/(ASCE)0733-9496(2001)127:6(378)

Lee, K. N. 1993. Compass and gyroscope: integrating science and politics in the environment. Island, Washington, D.C., USA.

Levin, S. 1999. Fragile dominion: complexity and the commons. Perseus Books, Cambrdige, Massachusetts, USA.

Li, T. M. 2006. Neoliberal strategies of government through community: the social development program of the World Bank in Indonesia. Institute for International Law and Justice, New York University School of Law, New York, New York, USA. 
McCay, B. J. 2002. Emergence of institutions for the commons: contexts, situations, and events. Pages 361-402 in E. Ostrom, T. Dietz, N. Dolsak, P. C. Stern, S. Stonich, and E. U. Weber, editors. The drama of the commons. National Academy Press, Washington, D.C., USA.

McCay, B. J., and J. M. Acheson, editors. 1987. The question of the commons: the culture and ecology of communal resources. University of Arizona Press, Tucson, Arizona, USA.

McGinnis, M. D. 2011. An introduction to IAD and the language of the Ostrom workshop: a simple guide to a complex framework. Policy Studies Journal 39:169-183. http://dx.doi.org/10.1111/ j.1541-0072.2010.00401.x

Meinzen-Dick, R. 2007. Beyond panaceas in water institutions. Proceedings of the National Academy of Sciences of the United States of America 104(39):15200-15205. http://dx.doi.org/10.1073/ pnas.0702296104

Mosse, D. 1997. The symbolic making of a common property resource: history, ecology and locality in a tank-irrigated landscape in south India. Development and Change 28(3):467-504. http://dx.doi.org/10.1111/1467-7660.00051

Nadasdy, P. 2003a. Reevaluating the co-management success story. Arctic 56(4):367-380.

Nadasdy, P. 2003b. Hunters and bureaucrats: power, knowledge, and aboriginal-state relations in the southwest Yukon. University of British Columbia Press, Vancouver, British Columbia, Canada.

Neumann, R. 2005. Making political ecology (human geography in the making). Oxford University Press, London, UK.

Newman, L. L., and A. Dale. 2005. Network structure, diversity, and proactive resilience building: a response to Tompkins and Adger. Ecology and Society 10(1): r2. [online] URL: http://www. ecologyandsociety.org/vol10/iss1/resp2/

Olsson, P., C. Folke, and F. Berkes. 2004a. Adaptive comanagement for building resilience in social-ecological systems. Environmental management 34:75-90. http://dx.doi. org/10.1007/s00267-003-0101-7

Olsson, P., C. Folke, and T. Hahn. 2004b. Social-ecological transformation for ecosystem management: the development of adaptive co-management of a wetland landscape in southern Sweden. Ecology and Society 9(4): 2. [online] URL: http://www. ecologyandsociety.org/vol9/iss4/art2/

Ostrom, E. 1990. Governing the commons: the evolution of institutions for collective action. Cambridge University Press, Cambridge, UK. http://dx.doi.org/10.1017/CBO9780511807763

Ostrom, E. 1999a. Coping with tragedies of the commons. Annual Review of Political Science 2:493-535. http://dx.doi.org/10.1146/ annurev.polisci.2.1.493

Ostrom, E. 1999b. Self-governance and forest resources. Center for Forestry Research, Jakarta, Indonesia.

Ostrom, E. 2005. Understanding institutional diversity. Princeton University Press, Princeton, New Jersey, USA.
Ostrom, E. 2007. A diagnostic approach for going beyond panaceas. Proceedings of the National Academy of Sciences of the United States of America 104(39):15181-15187. http://dx.doi. org/10.1073/pnas.0702288104

Ostrom, E. 2009. A general framework for analyzing sustainability of social-ecological systems. Science 325:419-422. http://dx.doi.org/10.1126/science.1172133

Ostrom, E. 2010. Beyond markets and states: polycentric governance of complex economic systems. American Economic Review 100(3):641-672. http://dx.doi.org/10.1257/aer.100.3.641

Ostrom, E. 2011. Background on the institutional analysis and development framework. Policy Studies Journal 39:7-27. http:// dx.doi.org/10.1111/j.1541-0072.2010.00394.x

Ostrom, E., R. Garderner, and J. Walker. 1994. Rules, games, and common-pool resources. University of Michigan Press, Ann Arbor, Michigan, USA.

Pahl-Wostl, C. 2007. Transitions towards adaptive management of water facing climate and global change. Water Resources Management 21:49-62. http://dx.doi.org/10.1007/s11269-006-9040-4

Pahl-Wostl, C., J. Sendzimir, P. Jeffrey, J. Aerts, G. Berkamp, and K. Cross. 2007. Managing change toward adaptive water management through social learning. Ecology and Society 12(2): 30. [online] URL: http://www.ecologyandsociety.org/vol12/iss2/ $\underline{\operatorname{art} 30 /}$

Pinkerton, E. W., editor. 1989a. Co-operative management of local fisheries. University of British Columbia Press, Vancouver, British Columbia, Canada.

Pinkerton, E. W. 1989b. Introduction: attaining better fisheries management through co-management - prospects, problems, and propositions. Pages 3-36 in E. W. Pinkerton, editor. Co-operative management of local fisheries. University of British Columbia Press, Vancouver, British Columbia, Canada.

Pinkerton, E. 1999. Factors in overcoming barriers to implementing co-management in British Columbia salmon fisheries. Conservation Ecology 3(2): 2. [online] URL: http://www. consecol.org/vol3/iss2/art2/

Pinkerton, E. W. 2003. Towards specificity in complexity: understanding co-management from a social science perspective. Pages 61-77 in D. C. Wilson, J. R. Nielson, and P. Degnbol, editors. The fisheries co-management experience: accomplishments, challenges and experiences. Kluwer Academic, Dordrecht, The Netherlands. http://dx.doi.org/10.1007/978-94-017-3323-6 5

Plummer, R. 2009. The adaptive co-management process: an initial synthesis of representative models and influential variables. Ecology and Society 14(2): 24. [online] URL: http://www. ecologyandsociety.org/vol14/iss2/art24/

Plummer, R., and D. Armitage. 2007a. Crossing boundaries, crossing scales: the evolution of environment and resource comanagement. Geography Compass 1(4):834-849. http://dx.doi. org/10.1111/j.1749-8198.2007.00040.x

Plummer, R., and D. Armitage. 2007b. A resilience-based framework for evaluating adaptive co-management: linking 
ecology, economics and society in a complex world. Ecological Economics 61:62-74. http://dx.doi.org/10.1016/j.ecolecon.2006.09.025

Plummer, R., and J. Fitzgibbon. 2004. Co-management of natural resources: a proposed framework. Environmental Management 33 (6):876-885. http://dx.doi.org/10.1007/s00267-003-3038-y

Plummer, R., and J. Fitzgibbon. 2007. Connecting adaptive comanagement, social learning, and social capital through theory and practice. Pages 38-61 in D. Armitage, F. Berkes, and N. Doubleday, editors. Adaptive co-management: collaboration, learning, and multi-level governance. University of British Columbia Press, Vancouver, British Columbia, Canada.

Pomeroy, R. S., and F. Berkes. 1997. Two to tango: the role of government in fisheries co-management. Marine Policy 21 (5):465-480. http://dx.doi.org/10.1016/S0308-597X(97)00017-1

Ribot, J. C., A. Agrawal, and A. M. Larson. 2006. Recentralizing while decentralizing: how national governments reappropriate forest resources. World Development 34(11):1864-1886. http://dx. doi.org/10.1016/j.worlddev.2005.11.020

Schlager, E., and E. Ostrom. 1992. Property-rights regimes and natural resources: a conceptual analysis. Land Economics 68 (3):249-262. http://dx.doi.org/10.2307/3146375

Selin, S., and D. Chavez. 1995. Developing a collaborative model for environmental planning and management. Environmental Management 19(2):189-195. http://dx.doi.org/10.1007/BF02471990

Sen, S., and J. R. Nielsen. 1996. Fisheries co-management: a comparative analysis. Marine Policy 20(5):405-418. http://dx.doi. org/10.1016/0308-597X(96)00028-0

Steins, N. A. 1999. All hands on deck: an interactive perspective on complex common-pool resource management based on case studies in the coastal waters of the Isle of Wight (UK), Connemara (Ireland) and the Dutch Wadden Sea. Dissertation. Wageningen University, Wageningen, The Netherlands.

Stern, P. C., T. Dietz, N. Dolsak, E. Ostrom, and S. Stonich. 2002. Knowledge and questions after 15 years of research. Pages 443-490 in E. Ostrom, T. Dietz, N. Dolsak, P. C. Stern, S. Stonich, and E. U. Weber, editors. The drama of the commons. National Academy Press, Washington, D.C., USA.

Taylor, S. 2001. Locating and conducting discourse analytic research. Pages 5-48 in M. Wetherell, S. Taylor, and S. J. Yates, editors. Discourse as data: a guide for analysis. The Open University, Milton Keynes, UK.

United Nations Environment Programme (UNEP). 2012. Global Environmental Outlook 5: environment for the future we want. UNEP, Nairobi, Kenya.

Wilson, D. C. 2010. Considering critical dualism: a response to Fikret Berkes. Mast 9:51-54. 